\title{
Integration of Agricultural Commodity Markets in Punjab
}

\author{
ZUBAIR TAHIR and KHALID RIAZ
}

\begin{abstract}
Efficiency of resource allocation in agriculture depends on the functioning of commodity markets. Although the larger markets that are better connected with the transport and communication network are expected to be well-integrated, the same cannot be said about the smaller, more remote markets. This paper tests integration of agricultural commodity markets in Southeastern Punjab. The region is located off the main trading axis of Pakistan, the Peshawar-Karachi highway, and is mostly served by relatively small markets known as mandis. This study focuses on markets for cotton, wheat, and rice in five towns in the region. Cotton and wheat are the main crops in the area while rice is mostly grown as part of crop rotation aimed at controlling salinity. The analytical framework developed by Ravallion was used to conduct tests of market integration for the three selected commodities. Within this framework, it is possible to test for short-run integration, long-run integration or complete market segmentation. The results indicate that, generally, markets are integrated only in the long run, with short-run integration limited to some special cases. Moreover, the smaller markets are more likely to be isolated as compared to the larger markets. The small markets also take longer to fully adjust to the price shock originating from a more dominant central market. Finally, in the case of rice, it is more likely that a market would be isolated if it were small. This implies that farmers' incentives to grow rice as a means of combating salinity may be constrained by local demand conditions.
\end{abstract}

\section{INTRODUCTION}

In a decentralised economic system resource allocation takes place through price signals transmitted by the markets. In developing economies, there are several impediments to the efficient functioning of markets, particularly agricultural commodity markets. These include, inadequate transportation infrastructure, difficulties in access to market information, government-imposed restrictions on movement of goods between regions, government monopoly over the marketing and distribution system, and poor enforcement of anti-trust regulation that results in price fixing and oligopolistic market structures.

If markets are not well-integrated, price signals are distorted, which leads to inefficient allocation of resources. But market integration also has other, more

Zubair Tahir is Assistant Research Economist at the International Irrigation Management Institute (IIMI), Pakistan. Khalid Riaz is Water Resources Economist, UN Department of Economic and Social Affairs, Sustainable Water Resources Management Project, Yemen.

Authors' Note: Research for this paper was conducted when both of us were affiliated with IIMI. We are grateful to IIMI for providing support for completing the research. We are also thankful to an anonymous referee of this journal for helpful comments. All views expressed in the paper are our own. 
specific, policy implications. For example, many governments try to stabilise prices of agricultural commodities, especially the prices of food products, either in an attempt to support farm incomes or as a part of food security policy. If markets are well-integrated, the government can stabilise prices in one key market and rely on arbitrage to produce a similar outcome in other markets. This reduces the cost of stabilisation considerably. Moreover, the impact on farm incomes of productivityenhancing public investments in irrigation and drainage depends on market integration. If markets are not well-integrated, the marketable surpluses these projects help generate could depress local prices and farm incomes, thus greatly diminishing the benefit farmers derive from such investment. Finally, in many regions, farmers' strategies for dealing with soil degradation problems involve judicious cropping pattern choices. For example, farmers adopt rice-salinity grass rotation on salinity-affected land because rice needs a lot of irrigation which also helps leach down salts [Neeltje (1996)]. If the local demand for these products is limited, farmers may have fewer incentives for adopting such a cropping pattern. ${ }^{1}$ On the other hand, if markets are well-integrated, farmers are not constrained by local demand conditions.

Many of the previous studies investigating the integration of agricultural commodity markets focused on large markets located along the main trading routes [e.g., Alderman (1993) and Haq (1992)]. A notable exception in this regard is Qureshi (1974), who focused on integration of village markets. The larger markets are typically linked through good transportation infrastructure (roads and railways) and are either hubs of surplus-producing regions or major demand centres. Most of these earlier studies found that although market integration was far from being perfect, there existed a fair degree of integration, especially in the long run. The question arises whether this conclusion also holds for smaller markets, off the main trading routes.

In Pakistan, as in most other developing countries, the majority of the population lives in rural areas dotted with small market towns. These towns are called mandi(s). The mandis are usually not very well-connected with the main transportation network unless they happen to lie along the Grand Trunk (GT) Road or the other main trading routes. Because they attract produce from a small area often comprising only the tehsil (sub-district) they are located in, each individual mandi tends to have a modest turnover. Perhaps for this reason, they have not figured prominently in market integration studies in Pakistan. ${ }^{2}$ This is an important gap in the literature because what happens in the small and medium markets influences a

${ }^{1}$ The local demand for foodgrains such as rice is limited in areas where rice is not the staple food and which are not located in close proximity to a large urban centre. Typically, these areas are those where rice is not a major crop [see Riaz (1994)]. The salinity-affected regions in South Punjab are an example of such areas where rice cultivation is mainly a part of reclamation efforts.

${ }^{2}$ The difficulty of collecting long enough time series of price for these small markets may be another reason for ignoring them. 
large segment of the population. This study aims at filling this gap by investigating the integration of small and medium markets. Three commodities are selected, namely, wheat, rice, and cotton. Although sugarcane is also grown in the area, difficulties in obtaining the required data prevented inclusion of this crop in the study.

\section{Markets and Commodities}

The geographic scope of the study is limited to the cotton-wheat zone in southeastern Punjab. This area is located off the main trading axis of the country, the Peshawar-Karachi highway. Five markets were selected, namely, Bahawalnager, Chishtian, Fort Abbas, Hasilpur, and Pakpattan. The first three markets are in Bahawalnagar district, Hasilpur is located in Bahawalpur district, and Pakpattan market is in Pakpattan district. Table 1 presents the acreage under different crops and population in the areas served by the selected markets.

Table 1

\section{Main Features of Selected Markets}

\begin{tabular}{lccccc}
\hline & Notified Area & Cultivated Area & Cultivated Area & Cultivated Area \\
Markets & (Sq. Km) & Estimated & $\begin{array}{c}\text { Wheat in Acres } \\
\text { (1994-95) }\end{array}$ & $\begin{array}{c}\text { Cotton in Acres } \\
\text { (1994) }\end{array}$ & $\begin{array}{c}\text { Rice in Acres } \\
(1994)\end{array}$ \\
\hline Hasilpur & 3436 & 322000 & 91966 & 92286 & 6302 \\
Chishtian & 1500 & 486000 & 136046 & 116156 & 7778 \\
Bahawalnagar & 1729 & 477000 & 640015 & 116349 & 116142 \\
Fort Abbas & 2536 & 344000 & 96299 & 69882 & - \\
Pakpattan & 1843 & 729000 & 213896 & 98233 & 57571 \\
\hline
\end{tabular}

Source: Bureau of Statistics, Punjab.

The areas served by these markets are located in the tail reaches of irrigation canals originating from the Sulaimanki headworks. ${ }^{3}$ Canal water is generally scarce except in areas near the heads of distributaries off-taking from the main canals. This has resulted in salinity problems. Although cotton and wheat are the main crops, rice and sugarcane are also grown in this area. Rice crop needs a lot of irrigation which also helps leach down salts. A significant proportion of land in the study area is salinity-affected and rice cultivation there is mainly a response to this problem. When rice is grown as a part of salinity mitigation strategy, its yields are generally low but the revenues from the sale of rice can partially or fully offset the cost of applying extra water for reclamation.

In the rest of this section a brief description of selected crops is presented.

${ }^{3}$ Three canals off-take from Sulaimanki Headworks. The Fordwah canal and the Eastern Sadiqia canal irrigate areas on the right bank of river Sutlej including areas served by the Bahawalpur, Chishtian, Hasilpur, and Fort Abbas markets. The Pakpattan canal serves areas in District Pakpattan which are on the left bank of Sutlej. 


\section{Cotton}

This is a major Kharif season crop in the selected markets. Different varieties of cotton are sown and marketed in the area. Market transactions of cotton are observed from September to March. Our interviews with different commission agents suggested that the price of seed cotton depended on the price of lint cotton. To understand this process, consider the following example. Suppose the price of lint is Rs 1900/40 kg. In $40 \mathrm{~kg}$. seed cotton there is approximately $13.5 \mathrm{~kg}$. lint (having the value of Rs 687 @ Rs 50.89/kg.) and $26 \mathrm{~kg}$. seed (having the value of Rs 163 @ 6.27/ kg.). So the price of cotton in the local market will be Rs $687+$ Rs $163=$ Rs $850 / 40 \mathrm{~kg}$. After subtraction of some commission by the agent, the price may be (approximately) Rs 815 per $40 \mathrm{~kg}$. This price formation process was observed in all selected markets.

\section{Rice}

South Punjab is not a major rice-growing area. However, rice is grown in the area either in response to salinity problems or near the head of a distributary where there is abundant water supply. The total turnover in each market is not as high as in the rice-growing areas in other parts of the country. So due to their small size, these markets may not be as well-integrated as other larger rice markets elsewhere in the country. Rice is not sown in the area around Fort Abbas due to its desert location, lack of canal water, and bad-quality ground water. Different varieties of rice are sown in the selected market areas but the most common is "Basmati 385". This variety was selected for the purposes of the present study. According to cultivated area figures shown in Table 1, Bahawalnagar and Pakpattan markets are the two larger rice markets among all selected markets, although they are not large as compared to markets in the main rice-growing areas (Sheikhupura, Gujranwala, Sialkot) in the province.

\section{Wheat}

Wheat is the major Rabi season crop. The acreage under wheat in each market area is greater than the acreage for any other crop. There are a lot of impediments to integration of wheat markets, including restrictions on its movement (Zila Bandi i.e., district boundary restriction) during certain months of the year to allow government agencies to meet their procurement targets. The government normally procures 25 percent to 30 percent of total wheat production. For this purpose, procurement centres are established in each market's notified area. Wheat is either procured directly from the farmers through the procurement centres ${ }^{4}$ or it is purchased on the open market. Farmers also keep some wheat for their own-consumption and as seed for next year's crop. Despite all these factors, sizeable quantities of wheat are transacted every year through open market.

${ }^{4}$ Some centres are temporarily established in the field during harvesting. 


\section{METHODOLOGY}

Market integration has been traditionally studied using static price correlations. The studies relying on correlation coefficient to infer spatial integration of agriculture prices include Jasdanwal (1966); Cummings (1967); Lele (1971); Muhammad (1975); Raju and Oppen (1982) and Jhala (1984). Despite their widespread use, there are inferential dangers in drawing conclusions from correlation coefficients or from regression coefficients estimated from static regressions. Ravallion (1986) pointed out that even if transportation cost between two markets were prohibitive, the time series of their prices could be affected by a shared dynamic seasonal pattern or the price of a third commodity traded in a common market. It would then be possible to obtain a high correlation coefficient or an estimated regression slope close to unity from a static regression. So the static correlation methods can lead to acceptance of the market integration hypothesis when, in fact, the markets are isolated.

The inferential danger pointed out above can be avoided by incorporating dynamic considerations into the model. Ravallion (1986) proposed a model that controlled for seasonality by allowing the local price to have its own dynamic structure. The model also allowed inter-linkage with other markets through which price shocks could be transmitted to the local market. A noteworthy feature of Ravallion's formulation was that instead of being limited to instantaneous adjustment, it allowed for the possibility that a price shock originating in one market could affect the price in another market with a lag. This feature is very important because market price adjustments in the real world seldom take place instantaneously. In Ravallion's framework, it is possible to test for both short-run and long-run price integration. Even when instantaneous integration was rejected, long-run integration could still hold.

Recognising that ordinary least square estimates become biased and inconsistent when there are endogenous regressors, Ravallion introduced the concept of a "reference" market. In his framework, the reference market is a dominant market serving as a hub in a sort of "radial market structure" where different feeder (local) markets are at the rim. ${ }^{5}$ The reference market dominates the price formation in the feeder markets. Every individual feeder market can be affected by the reference market price, but it alone can not affect the reference market price. However, various feeder (local) markets, taken together, may influence price in the reference market. Normally, the reference markets are dominant markets having a high turnover so that supply and demand shocks originating in the individual feeder markets are absorbed without much effect on the price prevailing in the reference markets. Examples include large supply centres located in the interior of agricultural regions, large

${ }^{5}$ The applicability of the Ravallion model is not limited to radial market structures and it can be used to study other market structures as well. 
metropolitan demand centres, and port cities providing export/import linkage to the rest of the world.

This study uses the Ravallion framework and applies it to markets in South Punjab. Ravallion assumed that there are $n$ local markets and the local prices in these markets $\left(P_{2} \ldots P n\right)$ are dominated by

$$
\begin{array}{rlllll}
P_{1} & =f_{1}\left(P_{2}, P_{3}, \ldots \ldots P_{n}, X_{1}\right) & \ldots & \ldots & \ldots & \ldots \\
P_{i} & =f_{i}\left(P_{1}, X_{i}\right) \quad i=2, \ldots, n & \ldots & \ldots & \ldots & \ldots
\end{array}
$$

one reference market price $\left(P_{1}\right)$. The Ravallion model can be represented as: Equation (2) postulates that prices in the feeder (local) markets are functions of the prices in the reference market $\left(P_{1}\right)$, where $X$ is the vector of the seasonal or policy variables. The above formulation is the most suited to a radial market structure. The econometric form of Equations (1) and (2) as suggested by Ravallion is:

$$
\begin{aligned}
& P_{1 t}=\sum_{j=1}^{1} \alpha_{1 j} P_{1 t-j}+\sum_{k=2}^{n} \sum_{j=0}^{1} b_{1 j}^{k} P_{k t-j}+c_{1} X_{1 t}+e_{1 t} \quad \ldots \quad \ldots \\
& P_{i t}=\sum_{j=1}^{1} a_{i j} P_{i t-j}+\sum_{j=0}^{1} b_{i j} P_{1 t-j}+c_{i} X_{i t}+e_{i t}(i=2, . ., n) \ldots \quad \ldots
\end{aligned}
$$

where the superscript $k$ indicates the markets and the subscript $j$, the lags.

Ravallion estimated Equation (4) acknowledging that in many circumstances Equation (3) was under-identified. Given the general model in Equation (4), the various hypothesis tests concerning market integration and their implied parametric restrictions are described below.

\section{Market Segmentation}

The first test concerns complete market segmentation. In Equation (4), if

$$
b_{i j}=0 \text { for all } j
$$

then the $i$ th market is segmented from the reference market. The restrictions involve testing that coefficients of the current price of the reference market and coefficients of all of its lag prices are, individually, equal to zero. If this restriction is accepted, then current and lagged prices of reference market do not influence the local market price. In other words, the price formation process in the local market is independent of conditions in the reference market.

\section{Short-run Integration}

Since adjustment to price shocks may take place over time, it is necessary to distinguish between short-run and long-run integration. The short run integration implies: 


$$
\begin{aligned}
& b_{i 0}=1 \\
& a_{i j}=b_{i j}=0 \quad j=(1, \ldots . n)
\end{aligned}
$$

If this hypothesis were to be accepted, it would imply that the entire price shock originating in the reference market is transmitted to the local market within a single time-period (a week in our case). Note that the above restriction forces only the coefficient of the current reference market price $\left(\beta_{i 0}\right)$ in Equation (4) to be nonzero. This implies that only the current period reference market price affects the local price, and the fact that this coefficient is unity means that the entire magnitude of the shock is transmitted within the same period.

\section{Long-run Integration}

Because agricultural markets are spatially separated, price changes in one market take time to influence the price in another market. Ravallion proposed the following test of market integration:

$$
\sum a_{i j}+\sum b_{i j}=1
$$

If the summation of all price variables in the equation is equal to 1, then local market is integrated with reference market in the long-run. In other words, price shocks in the reference market take more than a single time period to get fully transmitted to local market. But there is a long-run tendency for prices in the two markets to equalise. The failure of this condition to hold would imply noncompetitive market structure or impediments to mobility of goods, possibly due to poor infrastructure.

There are logical relationships between the various market integration restrictions presented above. If market segmentation restriction is accepted, for example, it implies a rejection of both the short-run as well as the long-run market integration restrictions. Short-run market integration implies long-run integration, but the reverse is not true, and it is very common to have markets that are integrated only in the long-run. This happens when price adjustment between the two markets is not instantaneous but price shock originating in the reference market is fully transmitted to the local market after a certain lag. Finally, there is another interesting possibility, that market segmentation, short-run market integration, and long-run market integration restrictions are all rejected, simultaneously. This situation arises when there is some lagged adjustment between the reference and the local market but 100 percent of the price shock from the reference market is not transmitted to the local market even in the long-run. Therefore, the two polar cases of market segmentation and long-run market integration proposed by Ravallion encompass, 
between themselves, varying degrees of market integration. Provided the market segmentation restriction is rejected, there is some adjustment in the local market price in response to variation in the price prevailing in the reference market. Whether this constitutes an acceptable degree of market integration is a matter of judgement, and depends on the purpose at hand.

\section{DATA}

For this study, the daily price data was obtained from rosters of market committee in each selected market. These rosters recorded daily low and high prices of each commodity. The price information was collected for the period from January 1993 to December 1995. Information for earlier periods was not available in easily accessible form. A series of daily prices was constructed for each commodity by averaging the relevant daily low and high price values. Next, the prices were aggregated into weekly prices. Weekly prices for each commodity were computed as an average of all daily prices in the week.

Wheat price series of all markets was continuous because wheat transactions take place in the market throughout the year. Price series of cotton and rice had gaps during the off-season when there is no trading in these commodities. This caused loss of some observations.

As discussed in the previous section, the analytical framework used in this study assumes that there is a dominant reference market for each commodity. For wheat and rice, Multan market was considered the reference market. This decision was motivated by discussions with commission agents/dealers, and the fact that Multan is a large commercial centre located on the Grand Trunk Road and serving as a hub for movement of goods to other parts of the country.

For cotton, however, the situation is somewhat more complicated. There is no single market for seed cotton that can serve as "reference market". This is because seed cotton is processed in local ginneries scattered all over the region. These ginneries separate seed from cotton lint and sometime also produce cottonseed oil. This poses considerable difficulty because the tests of market integration in the Ravallion model assume that integration is being studied between price series of the same commodity collected from two spatially separated markets. When the commodity moves up the processing chain before reaching the reference market (as in the case of cotton), the Ravallion type test of integration between the price of processed commodity in the reference market and the pre-processing stage price of the commodity in the local market can give misleading results. ${ }^{6}$ This difficulty was resolved by constructing an equivalent price of raw cotton based on the price of lint for the Karachi reference market, as obtained from the Karachi Cotton Association

${ }^{6}$ We tested the hypothesis for each market by using KCA's lint price as reference price. Not surprisingly, we found that all markets were segmented from the Karachi lint market. 
(KCA) records, and on cotton seed prices. ${ }^{7}$ The seed price was taken to be the price of cottonseed in Multan market. ${ }^{8}$

\section{RESULTS}

To test for market integration, Equation (4) in the Ravallion model was estimated using separate OLS regressions for cotton, rice, and wheat in each of the selected markets. The detailed results of these regressions are presented in the Appendix. The estimated equations employed several lags of local and reference market prices in addition to seasonal dummy variables. The lag length for each equation was determined using the F-test. The number of lags of the reference market price in any estimated equation indicates the number of weeks needed, beyond the current week, for a price shock to be fully transmitted from the reference market to the local market.

The remainder of this section deals with tests of the market integration hypothesis. The hypotheses considered were (a) market segmentation, (b) short-run market integration, and (c) long-run market integration. The tests of the market integration hypothesis were conducted using the F-test. The results are presented separately for each commodity in Tables 2-4 (for parameter estimates and more detailed regression results, see Appendices). All tables list the hypothesis to be tested in Column (i) and the corresponding calculated value of the F-statistic in Column (ii). The tabulated value of the F-statistic at 1 percent significance level and the appropriate degrees of freedom are reported in the third column. The last column contains remarks regarding the acceptance or rejection of the null hypothesis. The results of this analysis for each commodity are presented below.

\section{Cotton}

The results presented in Table 2 indicate that market segmentation is rejected for all cotton markets, as the calculated F-values are very large compared to the tabulated values with appropriate degrees of freedom. Hence, price formation in the selected markets does not take place completely independently of the equivalent price of cotton. Note that this result was obtained despite the fact that the selected markets are located off the main trading route of the country, the Karachi-Peshawar highway.

${ }^{7}$ More specifically, $40 \mathrm{Kg}$. of raw cotton contains roughly $13.5 \mathrm{Kg}$. lint, $26 \mathrm{Kg}$. seed and $0.5 \mathrm{Kg}$. of waste. The equivalent price of raw cotton was computed as the price of $13.5 \mathrm{Kg}$. cotton lint and $26 \mathrm{Kg}$. cotton seed. The lint price was taken to be the average of KCA price of three varieties (MNH93, K68, NIAB78) in the Karachi market.

${ }^{8}$ The commission agents told us that cottonseed of local area have main flow to Multan area due to large concentration of oil industry. So the Multan market seed price affects the local seed price, which is involved in price formation of cotton. 
Table 2

Cotton: Tests of Various Market Integration Hypotheses

\begin{tabular}{lrrrr}
\hline Hypothesis & F-Value & $\begin{array}{c}\text { Tabulated Value } \\
\mathrm{F}(\mathrm{n} 1 \mathrm{n} 2) \text { at } 1 \%\end{array}$ & Remarks & $\begin{array}{c}\text { Weeks Required } \\
\text { for Complete } \\
\text { Pransmission of } \\
\text { Price Signals }\end{array}$ \\
\hline Hasilpur & 12.5595 & $\mathrm{~F}(677)=3.22$ & Rejected & \\
Ho $=$ Mkt Segmentation & 46.7256 & $\mathrm{~F}(977)=2.60$ & Rejected & \\
Ho $=$ S.R. Integration & 4.8917 & $\mathrm{~F}(177)=6.96$ & Accepted & 6 \\
Ho $=$ L.R. Integration & & & & \\
Chishtian & 23.7140 & $\mathrm{~F}(2101)=4.81$ & Rejected & \\
Ho $=$ Mkt Segmentation & 154.4585 & $\mathrm{~F}(3101)=3.98$ & Rejected & \\
Ho $=$ S.R. Integration & 5.0004 & $\mathrm{~F}(1101)=6.88$ & Accepted & 2 \\
Ho $=$ L.R. Integration & & & & \\
Bahawalnagar & 22.3859 & $\mathrm{~F}(257)=4.98$ & Rejected & \\
Ho $=$ Mkt Segmentation & 31.4723 & $\mathrm{~F}(357)=4.13$ & Rejected & \\
Ho $=$ S.R. Integration & 10.1471 & $\mathrm{~F}(157)=7.08$ & Rejected & \\
Ho $=$ L.R. Integration & & & & \\
Fort Abbas & 10.2511 & $\mathrm{~F}(562)=3.34$ & Rejected & \\
Ho $=$ Mkt Segmentation & 6.9008 & $\mathrm{~F}(962)=2.72$ & Rejected & \\
Ho $=$ S.R. Integration & 0.0346 & $\mathrm{~F}(162)=7.08$ & Accepted & \\
Ho $=$ L.R. Integration & & & & \\
Pakpattan & 10.1141 & $\mathrm{~F}(560)=3.34$ & Rejected & \\
Ho $=$ Mkt Segmentation & 31.6043 & $\mathrm{~F}(960)=2.72$ & Rejected & \\
Ho $=$ S.R. Integration & 3.1641 & $\mathrm{~F}(160)=7.08$ & Accepted & 5 \\
Ho $=$ L.R. Integration & & & & \\
\hline
\end{tabular}

Having established that the cotton markets in South Punjab Cotton Belt are not completely isolated from the central lint market at Karachi, the next question is: What is the nature of the market integration. Are the markets integrated well enough to immediately transmit signals from the central market (short-run integration) or does this process involve lagged adjustment to changes in the central market's price?

The F-tests presented in Table 2 indicate that short-run market integration is rejected for all markets. This result was to be expected because of several reasons. First, the periodicity of the data used for this study is just one week, a period somewhat short for 100 percent of the price signal to be transmitted from the central market almost $1000 \mathrm{~km}$. away. Second, the integration involves two different stages in the processing chain (cotton lint and seed cotton). Therefore, instantaneous adjustment to the lint price shocks was not expected.

The picture vis-à-vis long-run integration was different. In all markets except Bahawalnagar, the hypothesis of long-run integration of seed cotton markets with the central lint market at Karachi could not be rejected. In view of the location of these markets off the main trade axis of the country, this is quite a remarkable result. It suggests that if sufficient time is allowed for adjustment, the price signals in the 
equivalent price of cotton get fully transmitted to most of the selected markets. The last column in Table 2 gives the time taken (in weeks) for complete transmission of the price signal from the reference market to the local market. The number of weeks taken for the price signal to be completely transmitted to the local market is equal to the number of lags of the reference market price variable in the regression equation, plus one. ${ }^{9}$ The results indicate that the time taken for complete transmission varied from six weeks for the relatively small cotton market at Hasilpur to only two weeks for the large Chishtian market. ${ }^{10}$

Bahawalnagar was the only cotton market found not integrated even in the long run. But note that the restrictions for market segmentation and short-run integration were also rejected for this market. As mentioned in the previous section, a situation like this arises when there is some transmission of price signal from the central market but one hundred percent of the price signal is not transmitted to the local market even in the long run. Several factors explain why this is so for the Bahawalnagar cotton market. First, the area surrounding Bahawalnagar has good canal water supply and, therefore, a lot of acreage under rice, the other major Kharif crop besides cotton. Consequently, the Bahawalnagar market is more specialised in rice, with less active cotton trading. Second, this conclusion is also supported by Bahawalnagar's proximity to a large and active cotton market at Chishtian ${ }^{11}$ (about $30 \mathrm{~km}$. away), which was found to be well-integrated in the long run with the central market.

\section{Rice}

The results of market integration tests for rice are presented in Table 3. Fort Abbas market is omitted because rice is not cultivated in that area. As mentioned earlier, the reference market for these tests was taken to be the rice market at Multan. The F-statistics reported in the table indicate that the Bahawalnagar and the Chishtian rice markets were both integrated with the Multan market. Whereas the Chishtian market was integrated with the Multan market only in the long run, the Bahawalnagar market was integrated even in the short run. This is consistent with the observation made earlier that Bahawalnagar region has abundant canal water supply resulting in sizable area under rice (see Table 1). The market intermediaries there are more specialised in rice trading. Hence, the almost instantaneous adjustment to changes in central market price.

\footnotetext{
${ }^{9}$ The addition of an extra week is necessary to account for the current week.

${ }^{10}$ Although data on market turnover are not available, an idea of the relative size of the markets can be had from cultivated area under the crop (Table 1).

${ }^{11}$ Chishtian market also is in Bahawalnagar district, so merchants do not have to pay octroi at district boundary. This is another reason that has helped specialisation of Bahawalnagar and Chishtian in rice and cotton respectively.
} 
Table 3

Rice: Tests of Various Market Integration Hypotheses

\begin{tabular}{|c|c|c|c|c|}
\hline Hypothesis & F-Value & $\begin{array}{l}\text { Tabulated Value } \\
\text { F(n1 n2) at } 1 \%\end{array}$ & Remarks & $\begin{array}{l}\text { Weeks Required } \\
\text { for Complete } \\
\text { Transmission of } \\
\text { Price Signals }\end{array}$ \\
\hline \multicolumn{5}{|l|}{ Hasilpur } \\
\hline Ho $=$ Mkt Segmentation & 2.9795 & $F(237)=5.22$ & Accepted & \\
\hline \multicolumn{5}{|l|}{ Chishtian } \\
\hline Ho = Mkt Segmentation & 13.0795 & $F(234)=5.27$ & Rejected & \\
\hline Ho = S.R. Integration & 44.0815 & $F(334)=4.39$ & Rejected & \\
\hline Ho $=$ L.R. Integration & 3.7356 & $F(134)=7.44$ & Accepted & 2 \\
\hline \multicolumn{5}{|l|}{ Bahawalnagar } \\
\hline Ho = Mkt Segmentation & 13.1924 & $F(332)=4.50$ & Rejected & \\
\hline Ho = S.R. Integration & 2.1335 & $F(532)=3.69$ & Accepted & 1 \\
\hline \multicolumn{5}{|l|}{ Pakpattan } \\
\hline Ho $=$ Mkt Segmentation & 2.0590 & $F(229)=5.42$ & Accepted & \\
\hline
\end{tabular}

The remaining markets, Hasilpur and Pakpattan, were found to be not integrated with the Multan market. The calculated $F$-values for these markets were smaller than the respective values from the $F$ distribution tables (Column 3), leading to a failure to reject the null hypothesis of market segmentation.

The segmentation of the Hasilpur rice market is due to the low turnover of rice in that market. Hasilpur is located at the tail-end of Fordwah and Azim distributaries where there is a general scarcity of canal water in the area. Not much rice is grown around these tail-end reaches of the canal system. The farmers who do cultivate rice have reclamation objectives. They are willing to incur the extra cost of supplemental tubewell water not for rice profits but because the extra water would leach down salts in addition to meeting irrigation requirements of this water-intensive crop. Rice sales just serve to offset all or part of the cost of extra water. In this context, the finding that Hasilpur market is isolated from the reference market has important implications. It raises the possibility that farmers' returns on rice may be depressed by low local demand. In this situation, the cost of salinity mitigation strategy would increase and fewer farmers would be inclined to adopt it, leading to adverse environmental consequences.

Results in Table 3 indicate that Pakpattan rice market is also segmented from the Multan rice market. This result is difficult to explain because the Pakpattan rice area is quite large (see Table 1). But note that the rice acreage in the district is large only in relation to other selected market areas; on a province-wide basis, Pakpattan is not major rice-growing district. Its population is the largest among the selected market areas. It is possible that most of the rice is consumed within local area or whatever is traded is destined for a market other than Multan (Lahore, for example) 
which has its own price dynamics. Pakpattan is located on the right bank of river Sutlej. The fact that Lahore, the second largest urban centre in Pakistan, is also situated on the right bank of river Sutlej, and is closer to Pakpattan than Multan, lends support to this conclusion.

The results in the last column of Table 3, regarding the time taken for complete price transmission, indicated that price transmission was much faster between rice markets as compared to cotton markets. However, even in the case of rice, the speed of adjustment was related to market size. The very big rice market at Bahawalnagar was integrated in the short run (1 week for complete transmission); the smaller Hasilpur market was isolated.

\section{Wheat}

Test result of hypotheses regarding various wheat markets are reported in Table 4. The results indicate that all selected wheat markets, except Hasilpur, were integrated with the Multan market in the long run. None of the wheat markets were integrated in the short run. As in the case of rice, the Hasilpur wheat market was also segmented from the Multan market.

Table 4

Wheat: Tests of Various Market Integration Hypotheses

\begin{tabular}{lrlll}
\hline Hypothesis & F-Value & $\begin{array}{c}\text { Tabulated Value } \\
\mathrm{F}(\mathrm{n} 1 \mathrm{n} 2) \text { at } 1 \%\end{array}$ & Remarks & $\begin{array}{c}\text { Weeks Required } \\
\text { for Complete } \\
\text { Transmission of } \\
\text { Price Signals }\end{array}$ \\
\hline $\begin{array}{l}\text { Hasilpur } \\
\text { Ho }=\text { Mkt Segmentation }\end{array}$ & 2.6729 & $\mathrm{~F}(3145)=3.78$ & Accepted & \\
Chishtian & & & & \\
Ho $=$ Mkt Segmentation & 4.0183 & $\mathrm{~F}(3149)=3.78$ & Rejected & \\
Ho $=$ S.R. Integration & 149.0959 & $\mathrm{~F}(5149)=3.02$ & Rejected & \\
Ho $=$ L.R. Integration & 0.2907 & $\mathrm{~F}(1149)=6.63$ & Accepted & \\
Bahawalnagar & & & & \\
Ho $=$ Mkt Segmentation & 6.9427 & $\mathrm{~F}(278)=4.91$ & Rejected & \\
Ho $=$ S.R. Integration & 37.4457 & $\mathrm{~F}(378)=4.08$ & Rejected & \\
Ho $=$ L.R. Integration & 2.8347 & $\mathrm{~F}(178)=7.01$ & Accepted & \\
Fort Abbas & & & & \\
Ho $=$ Mkt Segmentation & 3.5878 & $\mathrm{~F}(5114)=3.17$ & Rejected & \\
Ho $=$ S.R. Integration & 103.6379 & $\mathrm{~F}(9114)=2.56$ & Rejected & \\
Ho $=$ L.R. Integration & 0.5595 & $\mathrm{~F}(1114)=6.85$ & Accepted & \\
Pakpattan & & & & \\
Ho $=$ Mkt Segmentation & 6.1867 & $\mathrm{~F}(2122)=4.79$ & Rejected & \\
Ho $=$ S.R. Integration & 311.7482 & $\mathrm{~F}(3122)=3.95$ & Rejected & \\
Ho $=$ L.R. Integration & 3.7190 & $\mathrm{~F}(1122)=6.85$ & Accepted & \\
\hline
\end{tabular}


Wheat is a heavily regulated commodity. For many months during the year wheat movement between districts is banned. So wheat markets are expected to be less well-integrated, especially, in the short run. However, government is quite active in procurement of wheat and has its procurement centres all over the country. This might have led to better long-run market integration.

The results on the speed of adjustment presented in the last column of Table 4 confirm the pattern found in the case of cotton and rice. The larger wheat marketsBahawalnagar, Chishtian, and Pakpattan - took only two-to-three weeks to fully adjust to price shocks from the reference Multan market. The smaller wheat markets were either completely isolated (Hasilpur) or took considerably longer to adjust (five weeks for Fort Abbas).

\section{CONCLUSIONS}

Three main conclusions emerge from this study. First, the agricultural commodity markets in general are integrated only in the long run, with short-run integration limited to a few special cases. For some markets and commodities, the adjustment period is over a month. This suggests that there is scope for policy interventions to prevent post-harvest gluts and localised food shortages.

Second, the degree of market integration is not independent of market size. In particular, the smaller markets are more likely to be isolated. Also, the speed of transmission of the price shock from the reference market to the local market is related to the latter's size. Smaller markets, especially for cotton and wheat, take considerably longer to fully adjust to price shocks emanating from the reference markets.

Third, market integration has environmental implications. This is especially true for rice, which is grown in the study area as a part of salinity mitigation strategy. Some rice markets were found to be not-integrated even in the long run. This suggests that there is potential for local demand conditions to limit farmer incentives for adopting the particular salinity control strategy.

The conclusions regarding specific commodities are as follows. In the case of cotton, four out of five selected markets were integrated with KCA equivalent price of cotton in the long run. That is, if sufficient time was allowed, the price shocks in the KCA equivalent price were fully transmitted to local markets. So, any large increase or decrease in the production of cotton either due to an irrigation project or any environmental change (drainage project etc.) would not affect the local cotton price and the economic well-being of the farmers in the local area. However, given the length of the adjustment period, small cotton farmers who need to dispose of their produce immediately may face hardship.

The market integration tests for rice gave mixed results. The rice markets of Chishtian and Bahawalnagar were found integrated with the Multan (reference) market even in the short run. However, the Hasilpur and Pakpattan markets were segmented. 
Wheat markets were generally integrated only in the long run, and short-run integration was rejected for all wheat markets. This may be due to governmentimposed restrictions on the movement of wheat between districts that, generally, remain in place for several months during the year. The Hasilpur wheat market was found to be isolated even in the long run. As in the case of rice, this may be due to small turnover in the market.

The scope of the present study was limited to only five markets and three commodities. There is a need to conduct similar studies, covering more small and medium markets. Special attention needs to be paid to markets located in areas where land degradation problems are severe and farmers' reclamation strategies include specific cropping patterns, whose profitability may be affected by the degree of market integration. There is also a need to study other commodities, such as oilseeds and sugarcane.

\section{APPENDIX: REGRESSION TABLES}

The variable definitions are provided at the end of this appendix.

Appendix Table 1

Hasilpur Cotton Market

\begin{tabular}{lrrr}
\hline Variable & \multicolumn{1}{c}{$\mathrm{B}$} & \multicolumn{1}{c}{ Std. Error } & \multicolumn{1}{c}{ T-Ratio } \\
\hline HCOTTON1 & 0.66087 & 0.1077 & 6.137 \\
HCOTTON2 & 0.39164 & 0.1377 & 2.844 \\
HCOTTON3 & -0.29439 & 0.1395 & -2.110 \\
HCOTTON4 & $-0.33030 \mathrm{E}-02$ & 0.1408 & $-0.2345 \mathrm{E}-01$ \\
HCOTTON5 & $0.47624 \mathrm{E}-01$ & 0.1092 & 0.4361 \\
KCAECP & 1.0215 & 0.1245 & 8.206 \\
KCAECP1 & -0.77640 & 0.2031 & -3.823 \\
KCAECP2 & -0.27885 & 0.2108 & -1.323 \\
KCAECP3 & 0.12150 & 0.2071 & 0.5866 \\
KCAECP4 & -0.10386 & 0.1946 & -0.5338 \\
KCAECP5 & 0.19213 & 0.1407 & 1.365 \\
SNDUMY & 15.996 & 9.067 & 1.764 \\
JNDUMY & 66.913 & 20.83 & 3.212 \\
\hline
\end{tabular}

Dependent Variable: HCOTTONP.

R-Square $=0.9720$.

R-SQ Adjusted $=0.9676$. 
Appendix Table 2

Chishtian Cotton Market

\begin{tabular}{lrrr}
\hline Variable & \multicolumn{1}{c}{$\mathrm{B}$} & \multicolumn{1}{c}{ Std. Error } & T-Ratio \\
\hline CCOTTON1 & 0.82647 & $0.6395 \mathrm{E}-01$ & 12.92 \\
KCAECP & 0.62895 & $0.9622 \mathrm{E}-01$ & 6.537 \\
KCAECP1 & -0.47161 & 0.1089 & -4.332 \\
SNDUMY & 13.577 & 8.049 & 1.687 \\
JNDUMY & 32.844 & 21.12 & 1.555 \\
\hline
\end{tabular}

Dependent Variable: CCOTTONP.

R-Square $=0.9720$.

R-SQ Adjusted = 0.9676 .

Appendix Table 3

Bahawalnagar Cotton Market

\begin{tabular}{lrcr}
\hline Variable & \multicolumn{1}{c}{ B } & Std. Error & T-Ratio \\
\hline BCOTTON1 & 0.53209 & 0.1078 & 4.935 \\
KCAECP & 0.98822 & 0.2200 & 4.492 \\
KCAECP1 & -0.57147 & 0.2539 & -2.251 \\
SNDUMY & 32.527 & 15.65 & 2.078 \\
JNDUMY & 102.57 & 45.63 & 2.248 \\
\hline
\end{tabular}

Dependent Variable: BCOTTONP.

$\mathrm{R}$-Square $=0.8400$.

R-SQ Adjusted = 0.8287 .

Appendix Table 4

Fort Abbas Cotton Market

\begin{tabular}{lrcr}
\hline Variable & \multicolumn{1}{c}{$\mathrm{B}$} & Std. Error & T-Ratio \\
\hline FCOTTON1 & 0.77957 & 0.1351 & 5.772 \\
FCOTTON2 & -0.17989 & 0.1656 & -1.086 \\
FCOTTON3 & $0.28007 \mathrm{E}-01$ & 0.1611 & 0.1738 \\
FCOTTON4 & $0.84583 \mathrm{E}-01$ & 0.1402 & 0.6034 \\
KCAECP & 0.83979 & 0.1265 & 6.639 \\
KCAECP1 & -0.40213 & 0.1769 & -2.273 \\
KCAECP2 & $0.52739 \mathrm{E}-01$ & 0.1584 & 0.3330 \\
KCAECP3 & -0.34930 & 0.1588 & -2.199 \\
KCAECP4 & 0.14534 & 0.1299 & 1.119 \\
SNDUMY & 15.619 & 8.135 & 1.920 \\
JNDUMY & 26.745 & 22.76 & 1.175 \\
\hline
\end{tabular}

Dependent Variable: FCOTTONP.

R-Square $=0.9728$.

R-SQ Adjusted = 0.9685 . 
Appendix Table 5

Pakpattan Cotton Market

\begin{tabular}{lrcr}
\hline Variable & \multicolumn{1}{c}{$\mathrm{B}$} & Std. Error & T-Ratio \\
\hline PCOTTON1 & 0.55205 & 0.1241 & 4.447 \\
PCOTTON2 & 0.30298 & 0.1518 & 1.996 \\
PCOTTON3 & -0.35275 & 0.1360 & -2.593 \\
PCOTTON4 & 0.22529 & 0.1126 & 2.001 \\
KCAECP & 0.69018 & 0.1154 & 5.980 \\
KCAECP1 & -0.28099 & 0.1692 & -1.660 \\
KCAECP2 & -0.49233 & 0.1614 & -3.051 \\
KCAECP3 & 0.30784 & 0.1679 & 1.833 \\
KCAECP4 & $0.24380 \mathrm{E}-01$ & 0.1329 & 0.1835 \\
SNDUMY & 11.150 & 10.81 & 1.031 \\
JNDUMY & 76.861 & 24.75 & 3.105 \\
\hline
\end{tabular}

Dependent Variable: PCOTTONP.

R-Square $=0.9630$.

R-SQ Adjusted = 0.9569 .

Appendix Table 6

Hasilpur Rice Market

\begin{tabular}{lrcr}
\hline Variable & \multicolumn{1}{c}{ B } & Std. Error & T-Ratio \\
\hline HRICEP1 & 0.799 & 0.120 & 6.642 \\
MRICEP & 0.297 & 0.161 & 1.850 \\
MRICEP1 & $-0.62498 E-01$ & 0.197 & -0.317 \\
JNDUMY & -5.998 & 6.690 & -0.897 \\
\hline
\end{tabular}

Dependent Variable: HRICEP.

$\mathrm{R}$-Square $=0.8772$.

R-SQ Adjusted = 0.8672 .

Appendix Table 7

Chishtian Rice Market

\begin{tabular}{lrcr}
\hline Variable & B & Std. Error & T-Ratio \\
\hline CRICEP1 & 0.63896 & 0.1220 & 5.237 \\
MRICEP & 0.70265 & 0.1493 & 4.706 \\
MRICEP1 & -0.31236 & 0.1798 & -1.737 \\
JNDUMY & 15.405 & 8.222 & 1.874 \\
\hline
\end{tabular}

Dependent Variable: CRICEP.

$\mathrm{R}$-Square $=0.8682$.

R-SQ Adjusted = 0.8566 . 
Appendix Table 8

Bahawalnagar Rice Market

\begin{tabular}{lrcc}
\hline Variable & \multicolumn{1}{c}{$\mathrm{B}$} & Std. Error & T-Ratio \\
\hline BRICEP1 & 0.31514 & 0.1663 & 1.895 \\
BRICEP2 & 0.20973 & 0.1784 & 1.176 \\
MRICEP & 0.88460 & 0.1430 & 6.188 \\
MRICEP1 & -0.48912 & 0.2175 & -2.249 \\
MRICEP2 & $0.81123 \mathrm{E}-01$ & 0.1852 & 0.438 \\
JNDUMY & 7.7674 & 5.379 & 1.444 \\
\hline
\end{tabular}

Dependent Variable: BRICEP.

R-Square $=0.9520$.

R-SQ Adjusted = 0.9445 .

Appendix Table 9

Pakpattan Rice Market

\begin{tabular}{lccr}
\hline Variable & $\mathrm{B}$ & Std. Error & T-Ratio \\
\hline PRICEP1 & 0.73796 & 0.1409 & 5.236 \\
MRICEP & 0.40273 & 0.3888 & 1.036 \\
MRICEP1 & -0.10695 & 0.3884 & -0.2754 \\
JNDUMY & -9.4105 & 17.46 & -0.5391 \\
\hline
\end{tabular}

Dependent Variable: PRICEP.

R-Square $=0.1081$.

R-SQ Adjusted = 0.0159 .

Appendix Table 10

Hasilpur Wheat Market

\begin{tabular}{lrrr}
\hline Variable & \multicolumn{1}{c}{ B } & \multicolumn{1}{c}{ Std. Error } & T-Ratio \\
\hline HWHEATP1 & 0.60975 & $0.8305 \mathrm{E}-01$ & 7.342 \\
HWHEATP2 & 0.23827 & $0.8620 \mathrm{E}-01$ & 2.764 \\
MWHEATP & 0.23497 & 0.1399 & 1.679 \\
MWHEATP1 & -0.27673 & 0.1892 & -1.463 \\
MWHEATP2 & 0.19723 & 0.1297 & 1.521 \\
SNDUMY & -2.1492 & 1.425 & -1.508 \\
\hline
\end{tabular}

Dependent Variable: HWHEATP.

R-Square $=0.9315$.

R-SQ Adjusted $=0.9291$. 
Appendix Table 11

Chishtian Wheat Market

\begin{tabular}{lrrr}
\hline Variable & \multicolumn{1}{c}{$\mathrm{B}$} & \multicolumn{1}{c}{ Std. Error } & T-Ratio \\
\hline CWHEATP1 & 1.1213 & $0.8032 \mathrm{E}-01$ & 13.96 \\
CWHEATP2 & -0.20711 & $0.8213 \mathrm{E}-01$ & -2.522 \\
MWHEATP & 0.24804 & $0.8937 \mathrm{E}-01$ & 2.776 \\
MWHEATP1 & -0.10719 & 0.1264 & 0.8480 \\
MWHEATP2 & $-0.54133 \mathrm{E}-01$ & $0.8881 \mathrm{E}-01$ & 0.6096 \\
SNDUMY & -1.1329 & 0.8950 & -1.266 \\
\hline
\end{tabular}

Dependent Variable: CWHEATP.

$\mathrm{R}$-Square $=0.9666$.

R-SQ Adjusted $=0.9655$.

Appendix Table 12

Bahawalnagar Wheat Market

\begin{tabular}{lrrr}
\hline Variable & \multicolumn{1}{c}{ B } & Std. Error & T-Ratio \\
\hline BWHEATP1 & 0.68097 & $0.8663 \mathrm{E}-01$ & 7.861 \\
MWHEATP & 0.26331 & 0.1867 & 1.411 \\
MWHEATP1 & $0.47637 \mathrm{E}-01$ & 0.1850 & 0.2575 \\
SNDUMY & 1.3791 & 2.267 & 0.6085 \\
\hline
\end{tabular}

Dependent Variable: BWHEATP.

$\mathrm{R}$-Square $=0.8134$.

R-SQ Adjusted = 0.8062 .

Appendix Table 13

Fort Abbas Wheat Market

\begin{tabular}{lrrr}
\hline Variable & \multicolumn{1}{c}{$\mathrm{B}$} & \multicolumn{1}{c}{ Std. Error } & T-Ratio \\
\hline FWHEATP1 & 1.0522 & $0.9227 \mathrm{E}-01$ & 11.40 \\
FWHEATP2 & -0.38064 & 0.1246 & -3.055 \\
FWHEATP3 & 0.54483 & 0.1255 & 4.340 \\
FWHEATP4 & -0.31203 & $0.9647 \mathrm{E}-01$ & -3.235 \\
MWHEATP & 0.33864 & $0.8831 \mathrm{E}-01$ & 3.835 \\
MWHEATP1 & -0.28401 & 0.1182 & -2.404 \\
MWHEATP2 & $.65455 \mathrm{E}-01$ & 0.1214 & 0.5390 \\
MWHEATP3 & -0.13755 & 0.1210 & -1.136 \\
MWHEATP4 & 0.11074 & $0.8861 \mathrm{E}-01$ & 1.250 \\
SNDUMY & -0.78517 & 0.8491 & -0.9247 \\
\hline
\end{tabular}

Dependent Variable: FWHEATP.

R-Square $=0.9722$.

R-SQ Adjusted = 0.9700 . 
Appendix Table 14

Pakpattan Wheat Market

\begin{tabular}{lrrr}
\hline Variable & \multicolumn{1}{c}{ B } & Std. Error & T-Ratio \\
\hline PWHEATP1 & 0.85872 & $0.4281 \mathrm{E}-01$ & 20.06 \\
MWHEATP & 0.14283 & $0.9208 \mathrm{E}-01$ & 1.551 \\
MWHEATP1 & $-0.64805 \mathrm{E}-02$ & $0.9637 \mathrm{E}-01$ & $-0.6725 \mathrm{E}-01$ \\
SNDUMY & 1.6731 & 0.9542 & 1.753 \\
\hline
\end{tabular}

Dependent Variable: PWHEATP.

R-Square $=0.9751$.

R-SQ Adjusted = 0.9745 .

\section{VARIABLE DEFINITIONS}

\section{Cotton}

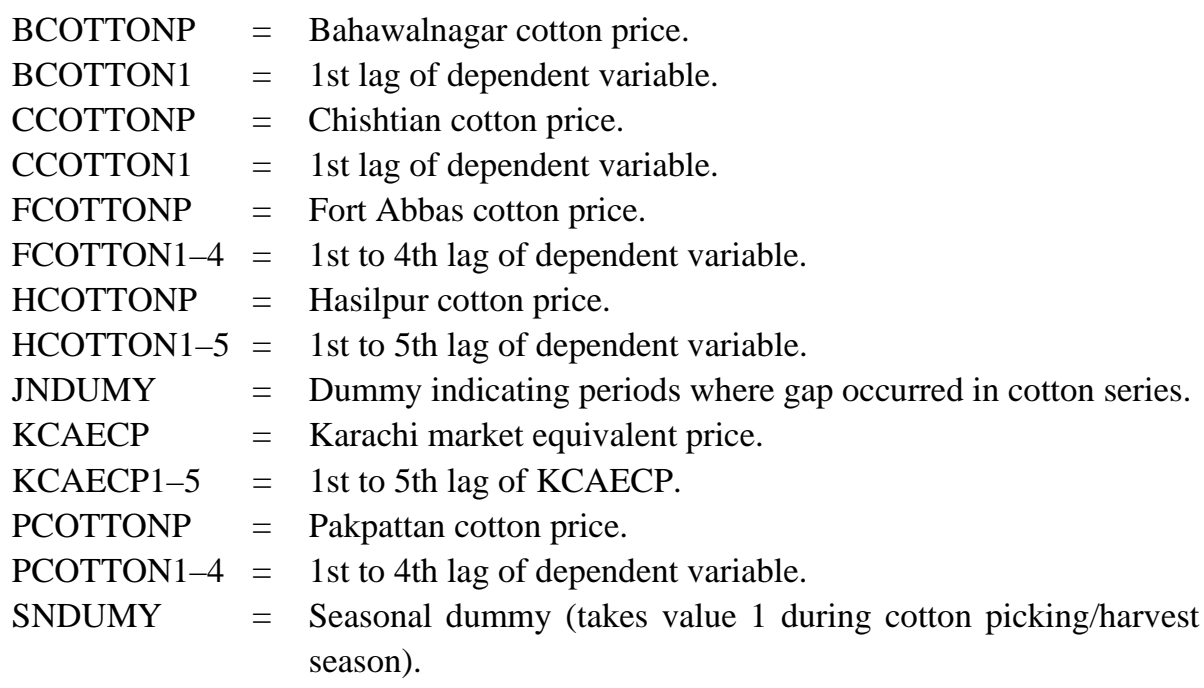

\section{Rice}

BRICEP $=$ Bahawalnagar rice price.

BRICE1-2 = 1st and 2nd lag of dependent variable.

CRICEP $=$ Chishtian rice price.

CRICE1 = 1st lag of dependent variable.

HRICEP $=$ Hasilpur rice price.

HRICE1 $=1$ st lag of dependent variable. 


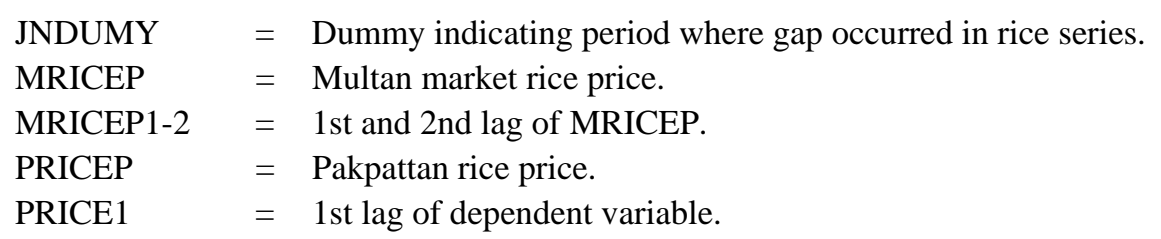

\section{Wheat}

BWHEATP $=$ Bahawalnager wheat price.

BWHEAT1 = 1st lag of dependent variable.

CWHEATP $=$ Chishtian wheat price.

CWHEAT1-2 = 1st and 2nd lag of dependent variables.

FWHEATP $=$ Fort Abbas wheat price.

FWHEAT1-4 $=$ 1st to 4th lag of dependent variable.

HWHEATP $=$ Hasilpur wheat price.

HWHEAT1-2 = 1st and 2nd lag of dependent variable.

MWHEATP $=$ Multan market wheat price.

MWHEATP1-2 $=1$ st and 2nd lag of MWHEATP.

PWHEATP $=$ Pakpattan wheat price.

PWHEAT1 $=1$ st lag of dependent variable.

SNDUMY $=$ Seasonal dummy (takes value 1 during wheat harvesting season).

\section{REFERENCES}

Alderman, H. (1993) Inter-commodity Price Transmittal: Analysis of Food Market in Ghana. Oxford Bulletin of Statistics and Economics 55: 43-64.

Cummings, W. Ralph (1967) Pricing Efficiency in the Indian Wheat Market. New Delhi: Impex.

Haq, N. U. (1992) Issues in Agricultural Pricing Policies in Pakistan. IFPRI, Islamabad. (Report.)

Jasdanwala, Zaibun Y. (1966) Marketing Efficiency in Indian Agriculture. Bombay: Allied Publishers.

Jhala, M. L. (1984) Restructuring Edible Oil and Oil Economy of India. Economic and Political Weekly 19:39 A-111-A-128.

Lele, Uma J. (1971) Food Grain Market in India. Ithaca, New York: Cornell University Press.

Mohammad, F. (1977) Pricing Efficiency in Agricultural Markets in Pakistan. Pakistan Institute of Development Economics, Islamabad. (Research Report Series No. 106.) 
Neeltje, C. Kielen (1996) Farmer's Ability to Cope with Salinity and Sodicity. International Irrigation Management Institute, Lahore. (IIMS Research Report No. 6.)

Qureshi, S. K. (1974) The Performance of Village Markets for Agricultural Produce: A Case Study of Pakistan. The Pakistan Development Review 13:3 280-307.

Raju, V. T., and M. Von Oppen (1982) Marketing Efficiency for Selected Crops in Semi-arid Tropical India. Economic Programme International Crops Research Institute for the Semi-arid Tropics. Patanchero, Andhra Pradesh, India. (ICRISAT Report No. 32.)

Ravallion, M. (1986) Testing Market Integration. American Journal of Agricultural Economics 68:1 102-129.

Riaz, K. (1994) Food Consumption Patterns in Rural Pakistan. Unpublished Ph.D. diss., Iowa State University, Iowa. 